ANEMIA FALCIFORME EXPERIÊNCIA: RELAÇÕES VULNERABILIDADE E CORPO DOENTE ENQ FENÔMENO BIOCU NO ESTADO D 


\section{ANEMIA FALCIFORME COMO} EXPERIÊNCIA: RELAÇÕES ENTRE VULNERABILIDADE SOCIAL E CORPO DOENTE ENQUANTO FENÔMENO BIOCULTURAL NO ESTADO DO PARÁ

\section{A R I A A KELLY L. SILVA DA SILVA}

SECRETARIA DE EDUCAÇÃO do PARÁ, BRASIL

$$
\text { H ILTON PEREIRA DA S I L VA }
$$




\title{
ANEMIA FALCIFORME COMO EXPERIÊNCIA: RELAÇÕES ENTRE VULNERABILIDADE SOCIAL E CORPO DOENTE ENQUANTO FENÔMENO BIOCULTURAL NO ESTADO DO PARÁ
}

\section{Resumo}

A Anemia Falciforme (AF) é uma doença crônica, hereditária, que tem elevada prevalência na população afrodescendente brasileira. $\mathrm{Na}$ Amazônia, ainda há poucos estudos sobre a realidade vivenciada pelos indivíduos por ela afetados. O agravo é entendido como um fenômeno biocultural por envolver aspectos evolutivos, genéticos, ambientais, socioeconômicos e culturais que influenciam a vivência cotidiana dos indivíduos. Esta pesquisa, de cunho qualitativo, etnográfico, foi realizada com uma amostra de 40 pessoas $H B^{*} S S$ - ou seus responsáveis, quando crianças - moradoras de diversos municípios do Estado do Pará, representando cerca de $10 \%$ das pessoas em tratamento no centro de referência em doenças hematológicas do Estado. Analisa-se a situação de vulnerabilidade social dos sujeitos, suas percepções de Saúde e Doença, os tratamentos complementares (folk medicine) utilizados, seu conhecimento sobre diagnóstico, estigmas e preconceitos sofridos, representações e experiências de vida, e suas dificuldades de acesso e acessibilidade aos serviços de saúde (SUS) na perspectiva de compreender a experiência de viver com AF.

Palavras-Chave: Anemia Falciforme, vulnerabilidade social, Amazônia

\section{SICKLE CELL ANEMIA AS EXPERIENCE: RELATIONS BETWEEN SOCIAL VULNERABILITY AND SICKNESS AS A BIOCULTURAL PHENOMENON IN THE STATE OF PARÁ}

\begin{abstract}
Sickle Cell Anemia (SCA) is a chronic, hereditary disease with high prevalence among people of African descent in Brazil. There are few studies about the reality of the affected individuals in the Amazon. SCA can be considered a biocultural disease as it involves evolutionary, genetic, environmental socioeconomic and cultural aspects which influence the daily living of the patients. This qualitative, ethnographic research was conducted with a sample of 40 individuals $H B^{*} S S$ - or their parents, when children - from several municipalities of Pará State representing about $10 \%$ of the people in treatment at the Para State reference center on blood diseases. The study investigates the social vulnerability, life experiences, perceptions of health and illness, use of folk medicine, stigma and prejudice suffered, and difficulty of access to public health services (SUS) of the individuals affected in order to understand the experience of living with SCA.
\end{abstract}

Keywords: Sickle Cell Anemia, social vulnerability, Amazonia 


\section{ANEMIA DE CÉLULAS FALCIFORMES COMO EXPERIENCIA: LAS RELACIONES ENTRE LA VULNERABILIDAD SOCIAL Y CUERPO ENFERMO COMO FENÓMENO BIOCULTURAL EN EL ESTADO DE PARÁ}

\section{Resumen}

La anemia de células falciformes es una enfermedad crónica, hereditaria, que tiene una alta prevalencia en personas de ascendencia africana en Brasil. En la Amazonía existen pocos estudios sobre la realidad que viven las personas afectadas por esta enfermedad. La queja se entiende como un fenómeno biocultural, ya que se refiere a aspectos evolutivos, genéticos, ambientales, socioeconómicos y culturales que influyen en la vida cotidiana de las personas. Esta investigación cualitativa, etnográfica, se realizó con una muestra de 40 personas $H B^{*} S S$ - o sus cuidadores en el caso de los niños - que viven en diferentes ciudades del estado de Pará, lo que representa alrededor del 10\% de las personas que reciben tratamiento en el centro de referencia hematológico del estado. La vulnerabilidad social de los sujetos, sus percepciones de la salud y la enfermedad, los tratamientos adyuvantes (medicina popular) utilizados, su conocimiento del diagnóstico, estigmas y prejuicios sufridos, representaciones y experiencias de vida, y las dificultades de acceso y la asequibilidad de los servicios de salud (SUS) fueron analizados para comprender la experiencia de vivir con anemia falciforme.

Palabras clave: Anemia de células falciformes, vulnerabilidad social, Amazonía

ARIANA KELLY LEANDRA SILVA DA SILVA. Endereço para correspondência: Av. Marquês de Herval, Vila Isabel, 133, Pedreira, Belém, Pará, 66087-730. E-mail: arianabelem@gmail.com. 


\section{INTRODUÇÃO}

De acordo com o Protocolo Hemominas (Brasil 1993), a Anemia Falciforme (AF) é entendida como:

Uma doença hereditária (...) A principal característica é a alteração do glóbulo vermelho do sangue e é muito frequente na população negra (preta e parda), mas também pode ocorrer em brancos. As pessoas com anemia falciforme recebem tanto do pai como da mãe hemoglobina tipo S. Elas são identificadas como SS. Os glóbulos vermelhos dessas pessoas, em determinados momentos, podem ficar no formato de foice ou meia-lua, que são mais rígidos e têm dificuldade para passar pelos vasos sanguíneos, dificultando a circulação do sangue (Brasil 1993: 2-3).

A AF é um agravo de considerável prevalência em populações variadas em todo o mundo, tendo sido descrita pela primeira vez pelo médico norte americano James Herrick, de Chicago, em 1910. Em 1904, ao examinar um paciente internado, um estudante universitário "negro" de 20 anos de idade, que apresentava uma série de sintomas (febre, tosse, cansaço, tontura, falta de ar, dor de cabeça e membranas mucosas visivelmente pálidas), Herrick realizou um exame sanguíneo detalhado, o qual revelou uma anemia acentuada, com hemácias irregulares pouco usuais, com células em forma de "foice", o que o levou, algum tempo depois, a anunciar a descoberta da entidade clínica AF (Perin et al. 2000).

Anualmente cerca de 25.000 a 30.000 pessoas nascem com Anemia Falci- forme $\left(H B^{*} S S\right)$ no Brasil. A ocorrência do Traço Falciforme $\left(H B^{*} A S\right)$ chega a 200.000 nascimentos por ano na população em geral (Cançado 2007). A estimativa da distribuição do gene $H B^{*} S$ no Brasil é bastante heterogênea, dependendo da composição etnogeográfica ou filogeográfica da população. A prevalência de alelos heterozigotos para a $\mathrm{HB}^{*} \mathrm{~S}$ é maior nas regiões Norte e Nordeste (6\% a 10\%); enquanto nas regiões Sul e Sudeste a prevalência é menor $(2 \%$ a $3 \%$ ). Independente da frequência, a AF constitui um sério problema de saúde pública no país (Zago et al. 1992).

De acordo com Paulo Cesar Naoum (2000), inúmeros fatores contribuem para as características da AF no Brasil:

A diversidade que caracteriza a anemia falciforme (no Brasil) está, em parte, relacionada à sua origem multicêntrica e que envolve populações com diferentes anormalidades genéticas de proteínas e enzimas eritrocitárias. Entre os interferentes ambientais destacamse as situações sociais, econômicas e culturais do doente, e que tem influência no curso de sua doença (Naoum 2000: 147).

A AF surgiu no continente africano e resulta de uma mutação genética, que tem em sua origem um evento microevolutivo (Lewin 1999). O processo seletivo ocorreu possivelmente há milhares de anos, como resultado de coevolução entre algumas populações humanas e o protozoário causador da malária (Plasmodium falciparum). A seleção natural favoreceu os indivíduos que possuíam a mutação em sua hemoglobina, em detrimento da hemo- 
globina considerada normal, representada por $H B^{*} A A$. Indivíduos heterozigotos, representados por $H B^{*} A S$, são mais resistentes à infecção pelo Plasmodium e desenvolvem uma forma mais branda da doença, que permite a sobrevivência de um maior número de indivíduos. À medida que o evento de fluxo gênico ${ }^{1}$ entre as populações ocorria - como ainda ocorre -, em algumas gerações, os heterozigotos $(A S)$ geravam descendentes homozigotos (SS), herdando um alelo $H B^{*} S$ do pai, outro da mãe, e outros heterozigotos, segundo proporções Mendelianas (Naoum 2010).

A doença chegou até as Américas através do tráfico negreiro, e posteriormente se dispersou pela miscigenação entre os diversos grupos humanos no continente ao longo do tempo (Pante-de-Sousa et al. 1998; Naoum 2000). Pesquisa recente sobre a frequência de haplótipos ${ }^{2}$ em dife- rentes municípios e estados do Brasil (Naoum 2011), mostra que, na cidade de Belém, a maior frequência do gene $S$ tem provável origem do grupo etnolinguístico Banto (África Subsaariana), com cerca de 66,7\% dos haplótipos, seguida por uma porção proveniente do Benin (África Ocidental), com $30 \%$, e outra do Senegal (Costa Oeste da África), com 3,3\% de frequência gênica (Tabela 1).

Naoum (2011: 8) esclarece que:

Estudos mostraram que os haplótipos Banto e Benin são predominantes; no entanto, as frequências variam de acordo com a região estudada. Estes resultados revelam um emprego heterogêneo de trabalhadores escravizados nos estados do Nordeste do Brasil, com resultados incrivelmente similares obtidos nas cidades de Rio de Janeiro e Salvador, bem como em Belém e Campinas.

Tabela 1.

Frequência de haplótipos de $H B^{*} S$ em diferentes cidades e estados do Brasil em relação a sua origem africana

\begin{tabular}{l|c|c|c|c|c}
\hline Cidade/Estado & Banto & Benin & Senegal & Camarões & Atípicos \\
\hline Rio de Janeiro/RJ & 54.0 & 44.5 & 1.5 & - & - \\
\hline Salvador/BA & 48.2 & 45.6 & 0.6 & - & 5.6 \\
\hline Fortaleza/CE & 31.8 & 43.1 & 2.3 & - & 22.8 \\
\hline Belém/PA & 66.7 & 30.0 & 3.3 & - & - \\
\hline Campinas/SP & 64.7 & 35.3 & - & - & - \\
\hline Ribeirão Preto/SP & 73.2 & 25.3 & 1.5 & - & - \\
\hline Recife/PE & 81.1 & 14.2 & - & 0.8 & 3.9 \\
\hline Porto Alegre/RS & 67.3 & 25.0 & 0.4 & 0.9 & 6.4 \\
\hline Total & 62.4 & 32.7 & 0.8 & 0.3 & 3.8 \\
\hline
\end{tabular}

Fonte: Naoum (2011:8) 
Na Amazônia, segundo Pante-de-Sousa et al. (1998) a ocorrência do gene $H B^{*} S$ também está relacionada ao processo de migração de escravizados desde meados do século XVIII, resultante do tráfico inter-regional de negros provenientes de outras regiões como o Nordeste. No estudo de Pante-de-Sousa et al. (1998), os autores asseguram que:

A distribuição esperada de haplótipos $\beta^{\mathrm{S}}$ em Belém era cerca de $86 \%$ de origem Banto, 9\% Benin e 4\% Senegal, com base em dados históricos sobre a importação direta de escravizados da África e considerando a distribuição de haplótipos $\beta^{S}$ entre as populações africanas de língua Banto e da África Ocidental. Isto não está de acordo com as frequências observadas: Banto $67 \%$, Benin 30\% e Senegal 3\% (Pante-de-Sousa et al. 1998: 427, tradução dos autores).

A diferença de haplótipos esperada para a cidade de Belém pode ser explicada apenas pela combinação de fatores relacionados à migração externa a partir do continente africano e pela migração interna, por meio de troca e venda de cativos já residentes no Brasil (Pante-de-Sousa et al. 1998).

A AF tem prevalência diversa entre os continentes e engloba processos de miscigenação e migração (fluxo gênico) que há milhares de anos contribuem para sua configuração socioespacial. Os dados epidemiológicos apontam que a $\mathrm{AF}$ se apresenta com características clínicas amplamente diferentes, frequentemente peculiares em relação aos indivíduos afetados e que estas independem dos haplótipos envolvidos.
Para efeito de desambiguação, a Anemia Falciforme (HB*SS), a S/Beta Talassemia ( $\mathrm{S} / \mathrm{B}$ Tal.), as doenças SC, SD, SE (duplos heterozigotos) fazem parte de um conjunto de alterações hematológicas que contém a hemoglobina variante $S$. Juntamente com outras formas mais raras, formam as chamadas hemoglobinopatias, conhecidas, em conjunto, como Doença Falciforme (DF) (Brasil 1993, 2006; Hutz 2010). O conceito de DF é, portanto, comumente usado para descrever variados tipos de hemoglobinopatias, sendo, a AF - objeto deste estudo - apenas uma delas, porém a mais prevalente em todo o mundo (Soares et al. 2009).

Por sua elevada prevalência no país, compreender esta ocorrência no estado do Pará é relevante para que possamos analisar social e antropologicamente seu impacto enquanto um problema de saúde pública e as consequências do adoecimento para as pessoas com o agravo (Batista 2008; Calvo-González e Rocha 2010).

A presente investigação está relacionada ao cotidiano biossocial de pessoas laboratorialmente confirmadas com $\mathrm{AF}\left(H B^{*} S S\right)$ pelo centro de referência estatal (Fundação Hemopa), apresentando os seus relatos e percepções.

A experiência de "viver com Anemia Falciforme"3 definitivamente é uma condição que além de biológica, requer também o enfrentamento e a convivência com agravantes sociais, que limitam sobremaneira o ir e vir, o ser, o estar e o viver das pessoas (Batista 2008). Especialmente aquelas que residem no interior do Estado, em áreas rurais, de 
beira de rio, ou mesmo em áreas urbanas onde os serviços de saúde são precários, sem especialistas ou profissionais que garantam minimamente o primeiro atendimento de urgência e emergência em situações de crise.

\section{METODOLOGIA}

Neste estudo, os esforços foram concentrados em uma amostra de 40 (quarenta) pessoas com Anemia Falciforme $\left(H B^{*} S S\right)$ moradoras de diversos municípios do estado do Pará, tendo como locus da pesquisa o centro de referência em doenças hematológicas e afins do Estado do Pará (Fundação Centro de Hemoterapia e Hematologia do Estado do Pará), em Belém.

A pesquisa adotou estratégia de amostragem de conveniência por saturação (Fontanella et al. 2008), considerando o "princípio da saturação" (Guerra 2008: 40-41) no qual o pesquisador, após certo número de entrevistas, tem a percepção de ter obtido a resposta necessária à sua pergunta por acúmulo de opiniões que tendem a se repetir.

A abordagem metodológica foi baseada na perspectiva da Antropologia da Doença que, segundo François Laplantine (2004), engloba:

O estudo do comportamento humano à obtenção de categorais de saúde e doença embasadas em práticas socioculturais enquanto representação do pluralismo etiológico-terapêutico em nossa sociedade, especialmente pelo fato de existirem distintas medicinas em campos extremamente diversifica- dos e que, por isso mesmo, devem ser levados em suma e igual importância (Laplantine 2004: 12-13).

Após obter o parecer favorável do Comitê de Ética em Pesquisa (Folha de Rosto n. 399909), iniciou-se um conjunto de "conversas com finalidade" (Minayo 2000) usando um contínuo de observação e perguntas abertas, com mulheres, homens, adolescentes e crianças com AF, as últimas sendo representadas por seus respectivos pais ou mães. Estas pessoas foram acompanhadas ou estavam no hemocentro por ocasião de consultas agendadas, transfusão de sangue, atendimento de urgência, acolhimento de enfermagem, odontologia ou exames periódicos de rotina, este último, o atendimento mais frequente aos usuários que fazem tratamento na instituição $(30 \%)$.

O contato com os entrevistados se realizou de maneira direta com os sujeitos que aguardavam procedimentos na Fundação Hemopa. O critério de inclusão foi estabelecido pelo número de pessoas que compareciam no hemocentro para acompanhamento clínico durante o período da pesquisa. No setor administrativo do Hemopa, foi possível ter acesso ao sistema interno de informações sobre diagnóstico e dados demográficos como nome, idade e cidade de moradia. Com o apoio de servidores do setor de recepção foram identificadas as pessoas que poderiam ser informantes. Durante a primeira abordagem, com cada interlocutor era feita uma breve apresentação da entrevistadora, da instituição da pesquisa, do objetivo da "conversa", e se 
precedeu a entrevista sobre o cotidiano biossocial dos indivíduos. Em um segundo momento, após o atendimento clínico, foram iniciadas as "conversas com finalidade” (Minayo 2000).

A análise do cotidiano dos sujeitos foi realizada sob a perspectiva teórica de Paulo César Alves e Miriam Cristina Rabelo (1998) que consideram em suas pesquisas "o contexto de representação social da doença como experiência”, e afirmam que:

Cientistas sociais contemporâneos têm apontado para a necessidade de se reelaborar as relações entre pensamento e ação; consciência e corpo; cultura e individualidade. $\mathrm{O}$ conceito de experiência tem sido desenvolvido como campo em que se entrecruzam essas dimensões, oferecendo assim caminho interessante para uma possível superação das dicotomias clássicas (Alves e Rabelo 1998: 108-109).

A metodologia compreensiva, de acordo com a concepção de Isabel Guerra (2008), também serviu de embasamento para as análises, por englobar a identificação de práticas cotidianas que elucidam ou transformam, no bic et nunc as dinâmicas sociais, as regras ou as instituições existentes. Segundo a autora:

O ponto de partida [da metodologia compreensiva] associa a análise da racionalidade dos actores à atenção aos modelos de interacção entre os sujeitos e os sistemas sociais, no contexto de um "sistema de acção" socialmente construído onde os contextos transcendem as situações imediatas (Guerra 2008: 09).
Os pressupostos metodológicos foram fundamentados na postura analítica e na reconstrução de sentido dos relatos dos interlocutores, com a finalidade de compreender a diversidade de entendimentos que representam o mundo a partir de suas vivências com um "sentido de ação", apoiado na perspectiva de "tornar objetiva a subjetividade", conforme salienta Guerra (2008):

Assentado numa grande diversidade de posturas teóricas, os paradigmas compreensivos consideram que o foco da análise incide sobre o sentido da ação e as diferentes racionalidades dos actores e que o desafio é "tornar objetiva a subjetividade". (...) Hoje, valorizam-se as entrevistas de per si e tenta-se estabelecer as situações em que elas devem ser aplicadas (Guerra 2008: 31).

A interpretação do relato de experiências dos interlocutores foi realizada através do método de "análise de conteúdo" que, na concepção de Guerra (2008), consiste em:

Uma dimensão descritiva que visa dar conta do que nos foi narrado e uma dimensão interpretativa que decorre das interrogações do analista face a um objecto de estudo, com recurso a um sistema de conceitos teóricoanalíticos cuja articulação permite formular as regras de inferência (Guerra 2008: 62).

Para Guerra (op.cit.) a análise de conteúdo das narrativas requer que o pesquisador consiga delinear sua compreensão para obter suposições qualitativas no entendimento do discurso dos interlocutores, que falam de um lugar e tempo definidos, e também 
pela possibilidade de explorar ideaistipo - o conjunto de unidades de indivíduos, grupos, fatos, etc., como instrumento para compreender a ação social, um sistema de pensamento de relações abstratas - dos sujeitos históricos que constituem a pesquisa, com a possibilidade de desenvolver generalizações.

A técnica de dedução das narrativas também foi empregada com a intenção de obter a generalização de opiniões como resultado posterior da pesquisa (Mauss 1979a, 1979b).

Ao elaborar o questionário sobre o cotidiano das pessoas com AF, tentou-se delimitar a compreensão da representação social ${ }^{5}$ (Sevalho 1993) e do agravo enquanto perspectiva da "doença como experiência" (Alves e Rabelo 1998), considerando as experiências de vida/morte e de vivência dos interlocutores, com o intuito de apresentar uma noção sobre o corpo enquanto domínio de adoecimento.

O trabalho etnográfico consistiu na efetivação dos contatos com as pessoas com AF e durou oito meses, sendo realizado no ambulatório do Hemopa, nas salas de espera de pacientes e doadores, no setor de acolhimento de enfermagem, nas salas de transfusão pediátrica e adulta e nas imediações do consultório de odontologia e do ambulatório médico, locais onde se aguardava a saída dos participantes para iniciar a fase mais delicada do contato, a explicação detalhada ao interlocutor ou interlocutora do TCLE - Termo de Consentimento Livre e Esclarecido, seguindo a Resolução ANS 196/96 - e posteriormente, iniciar a entrevista.
A pesquisa qualitativa em saúde (Guerra 2008) é uma tarefa que exige cuidado redobrado por se encontrar em um contexto de liminaridade. Neste caso tem-se, de um lado, o sujeito que concorda em colaborar com a pesquisa - por altruísmo, curiosidade ou espontaneidade; de outro, a sua ansiedade pela consulta, para verificar se o remédio está disponível na farmácia, de marcar o retorno no ambulatório, de encontrar o funcionário da sorologia e levar o resultado para o médico, de fazer o teste de hemoglobina com o intuito de averiguar se precisa de transfusão e tantas etapas da rotina que o usuário enfrenta quando em visita ao hemocentro.

No decorrer da primeira abordagem, os muitos ruídos externos, como o som dos painéis eletrônicos que chamavam para suas consultas; o barulho de entra e sai de uma sala para outra; de pessoas chamando repetidamente o nome de alguém que, após quase três longas horas de espera para atendimento, provavelmente havia saído para tomar um lanche ou ir ao banheiro; de choro de crianças impacientes, com ou sem dor, inquietas com a demora do médico que "já deveria ter chegado"; de pequenos resmungos no balcão de cadastro de usuários pelo "funcionário que saiu e nunca mais voltou"; de burburinhos paralelos de indivíduos que se conhecem por ocasião da condição de serem pacientes (por enfermidade ou pela "arte paciente" de saber esperar a sua vez); formaram o cenário da maioria das conversas que, gentilmente, as pessoas concordaram em realizar. 
Frequentemente, devido ao barulho, o processo de entrevista foi realizado em outros ambientes do Hemocentro, como a sala de espera de doadores, as salas de enfermagem e de transfusão, etc. A interação entre pesquisadora e pesquisado foi frequentemente contornada de sorrisos, lágrimas, olhares profundos, mãos firmes que gesticulam sentimentos cotidianos de dor, tristeza, fé e possibilidade de cura; com mães e pais acolhedores, adolescentes precocemente amadurecidos pela doença, adultos experientes que, por meio de suas falas e contextos sociais, lucidamente emitem gostos, práticas, gestos, ações e vontades diversas, e que, sobretudo, falam a respeito da vida de maneira singular.

\section{RESULTADOS}

O número de pessoas com AF participantes desta pesquisa representa cerca de $10 \%$ dos casos confirmados de $H B^{*} S S$, envolvendo apenas os indivíduos cadastrados e ativos no hemocentro até dezembro de 2010.

As redes de acolhimento familiar e institucional (capital social) nem sempre são adequadas para o bem estar pleno dos interlocutores. A suscetibilidade física, emocional e material das pessoas com AF é parte dos Determinantes Sociais ${ }^{7}$ em Saúde que caracterizam o cotidiano dos indivíduos, que vivem cercados de incertezas dadas à imprevisibilidade da doença (Brasil 1993).

Entre os sujeitos entrevistados, a situação de vulnerabilidade social abrange cerca de $40 \%$ das famílias, que vivem com até 1 (um) Salário Mínimo (SM, equivalente a $\mathrm{R} \$$ 545,00, em 2011). Deste percentual, cerca de 15\% conta com renda familiar entre $\mathrm{R} \$ 150,00$ e R \$300,00 por mês, especialmente aqueles que não recebem algum tipo de benefício governamental ou "Auxílio Doença", como é conhecida a ajuda de custo do Ministério da Previdência Social para que pessoas com doenças crônico-degenerativas - entre outros agravos - possam ter acesso ao tratamento de saúde. ${ }^{8}$ A AF contribui para a situação de vulnerabilidade social seja por causar desequilíbrio financeiro, seja pelo estresse psicossocial que o agravo acarreta para o sujeito em constante necessidade de insumos terapêuticos.

Os dados da tabela 2 confirmam que a situação socioeconômica dos indivíduos é de vulnerabilidade social, uma vez que a maioria convive com uma renda que impõe graves limites a seu tratamento de saúde que, além da necessidade de terapêutica contínua, inclui o deslocamento frequente de seus municípios para atendimento na capital do estado e obriga a dependência exclusiva de serviços do SUS, que nem sempre têm cobertura específica para pessoas com AF - salvo o Hemopa. Dificuldades econômicas se transformam em barreiras estruturais durante as frequentes crises de dor, na medida em que os interlocutores necessitam de internações hospitalares frequentes e inexistentes no interior do estado. A situação de pobreza se agrava ainda mais nos casos em que há restrição para conseguir emprego devido ao déficit escolar ou às crises repetidas, entre outras situações. 


\section{ANEMIA FALCIFORME COMO EXPERIÊNCIA DE VIDA:}

\section{A VULNERABILIDADE SOCIAL}

A vicissitude de conviver com $\mathrm{AF}$ é uma situação que requer a compreensão biológica da doença, pelas inúmeras crises álgicas que acometem os indivíduos, pelas complicações hematológicas que evoluem constantemente à esplenomegalia, síndrome mão-pé (que ocorre principalmente em crianças, com inchaço das articulações das mãos e dos pés), Acidente Vascular Cerebral (por dificuldades de circulação sanguínea), Icterícia, Priaprismo, Febre (que demanda atendimento médico imediato por indicar provável processo inflamatório) e fatores fisiológicos diversos (Brasil 2007). Demanda tam-

Tabela 2.

Sexo, faixa etária, renda familiar, local de moradia e porcentagem dos serviços do SUS mais utilizados pelos interlocutores com AF atendidos na Fundação Hemopa, Belém $(n=40)$.

\begin{tabular}{l|c|c|c|c}
\hline Interlocutores & $\begin{array}{c}\text { Sexo } \\
\text { Feminino }\end{array}$ & $\begin{array}{c}\text { Sexo } \\
\text { Masculino }\end{array}$ & $\begin{array}{c}\text { Faixa } \\
\text { Etária }\end{array}$ & Déficit Escolar \\
\hline Crianças & 06 & 04 & $05-11$ & $14 \%$ \\
\hline Adolescentes & 03 & 06 & $12-17$ & $36 \%$ \\
\hline Adultos & 10 & 11 & $18-49$ & $50 \%$ \\
\hline $\begin{array}{l}\text { Total } \\
(\mathrm{n}=40)\end{array}$ & 19 & 21 & - & - \\
\hline
\end{tabular}

\begin{tabular}{l|l|l|l|l}
\hline $\begin{array}{l}\text { Renda Familiar } \\
(\%)^{*}\end{array}$ & $\begin{array}{l}\text { Nível 1 } \\
(40 \%)\end{array}$ & $\begin{array}{l}\text { Nível 2 } \\
(35 \%)\end{array}$ & $\begin{array}{l}\text { Nível 3 } \\
(13 \%)\end{array}$ & Nível 4 (12\%) \\
\hline
\end{tabular}

\begin{tabular}{|c|c|c|c|c|c|}
\hline $\begin{array}{l}\text { Principais } \\
\text { locais de mo- } \\
\text { radia }(\%)^{* *}\end{array}$ & $\begin{array}{l}\text { Belém } \\
(30 \%)\end{array}$ & $\begin{array}{l}\text { Paragomi- } \\
\text { nas } \\
(8 \%)\end{array}$ & $\begin{array}{l}\text { Breu } \\
\text { Branco } \\
(5 \%)\end{array}$ & $\begin{array}{l}\text { Marabá } \\
(3 \%)\end{array}$ & $\begin{array}{l}\text { Ananindeua } \\
(3 \%)\end{array}$ \\
\hline $\begin{array}{l}\text { Serviços do } \\
\text { SUS mais } \\
\text { utilizados } \\
(\%)\end{array}$ & $\begin{array}{l}\text { Fundação } \\
\text { Hemopa } \\
(100 \%)\end{array}$ & $\begin{array}{l}\text { Pronto } \\
\text { Socorro } \\
(50 \%)\end{array}$ & $\begin{array}{l}\text { Posto de } \\
\text { Saúde } \\
(45,5 \%)\end{array}$ & $\begin{array}{l}\text { Hospitais Mu- } \\
\text { nicipais } \\
(15 \%)\end{array}$ & $\begin{array}{l}\text { Hospital Ophir } \\
\text { Loyola } \\
(12,5 \%)\end{array}$ \\
\hline
\end{tabular}

* Nível Salarial: 1 (até 1 Salário Mínimo), 2 (entre 1 e menos de 2 SM), 3 (entre 2 e menos de 3 SM) e 4 (entre 3 e 4 SM ou mais).

** As demais localidades de moradia dos interlocutores entrevistados foram: Abaetetuba (3\%), Bragança (3\%), Cametá (3\%), Capanema (3\%), Curionópolis (2\%), Curuçá $(5 \%)$, Eldorado dos Carajás (3\%), Igarapé Miri (3\%), Muaná (2\%), Novo Repartimento (3\%), Oeiras do Pará (3\%), Parauapebas (3\%), Portel (2\%), Santa Isabel do Pará $(2 \%)$, Santa Maria do Pará (2\%), São Francisco do Pará (3\%), Jacundá (3\%) e Uruará (3\%).

Fonte: Dados da pesquisa de campo. 
bém o enfrentamento dos agravantes sociais, que incluem sofrer discriminação sociorracial, limitações de acesso e acessibilidade ao atendimento de saúde, especialmente aqueles que residem em áreas rurais, ribeirinhas, com grandes dificuldades de transporte, ou mesmo em áreas urbanas, nas quais os serviços de transporte são precários.

Além disso, na maioria dos locais do Estado não há especialistas ou mesmo profissionais que garantam minimamente $O$ primeiro atendimento de urgência em situações de crise.

Durante as entrevistas, ao indagar às pessoas se eles e elas conheciam, sabiam conceituar ou do que se tratava a doença, a maioria dos entrevistados (75\%) disse que sim, que sabia o que era AF. Os relatos mais frequentes classificaram a AF como "doença hereditária que é passada dos pais para os filhos, que deforma os glóbulos vermelhos e que não tem cura" e que, como pode ser visto a seguir, acomete pessoas negras ou está relacionada aos antepassados.

A doutora disse que a Anemia Falciforme veio da África, de acordo com a mistura, os brancos se envolveram com os negros, são as letras do pai e da mãe, ela teve duas letras SS (Luiza, agente de serviços gerais, mãe de criança de 5 anos).

Eu não sei realmente se é isso que vou te falar, é uma doença genética que passa de pai pra filho, que dá apenas em pessoas de cor escura. Como eu sou branco, de olho azul (pensativo)... Não sei porquê eu tenho (Pedro, autônomo, 45 anos).
Agora eu tô sabendo. É uma doença hereditária, que passa dos pais pros filhos. Descende do meu avô, que era negro e essa doença vem do negro. Meu avô trouxe o traço, somos oito irmãos, foi o dela [filha] e do filho do meu sobrinho (Maria, do lar, mãe de adolescente de 14 anos).

É uma doença genética, hereditária, trazida da África através dos escravos, da colonização e difundida para outros estados, países, continentes. Tendo como principal consequência as crises dolorosas, que é o meu caso, com dores intensas, que passei a sentir desde os seis meses de idade (Joana, pedagoga, 35 anos, Belém).

$\mathrm{O}$ que me explicaram é que a $\mathrm{AF}$ passa de pai pra filho, que vem no nosso sangue, dos antepassados nossos, que ainda tem essa herança aî que nós tivemos, a minha filha tem o traço e se juntou com o pai dela que também tem o traço, descobri isso nas palavras dos panfletos (Benvinda, aposentada, avó de adolescente de 14 anos).

A AF é de origem genética, e assim é percebida pelos interlocutores. Entretanto, o conceito "hereditário" nas suas falas relaciona esta palavra a um passado ancestral de natureza "racial" (Munanga 2003), a um antepassado longínquo africano, a uma doença que "vem do negro". Todavia, a expressão não tem a conotação de identidade com o fato de ser fenotipicamente "negro" ou "negra", de ter identificação com a causa política, de assumir uma "negritude de fato e de direito", como é o caso do Movimento Negro Brasileiro 
(Domingues 2007). Assim sendo, nota-se que a percepção sobre a AF é de que a "doença que vem do negro" é um problema social, que está atrelado a um passado biológico, que é negativo e por vezes, punitivo - a "Doença Maldição", expressada por Laplantine (2004: 227) - pois as pessoas se perguntam: "Por que isso aconteceu comigo, o que eu fiz de errado?" ou mesmo, "Não entendo por quê eu tenho AF. Eu sou branco". ${ }^{10}$ As falas são de pessoas de ambos os sexos, que referenciam o "negro" como um ancestral ou parente distante, sem grandes menções a si mesmas.

A vulnerabilidade social é uma situação que não está presente apenas entre pessoas com AF; todavia, como o agravo requer cuidado e acolhimento imediatos devido à condição de doença crônica ${ }^{11}$ (Canesqui et al. 2008), que se agudiza com frequência, o estado de pobreza e a limitação do acesso aos serviços de saúde (Cavalcante 2011) dificultam sobremaneira a adesão ao tratamento, que deve ser contínuo.

\section{ANEMIA FALCIFORME E IDENTIFICAÇÃO ÉTNICO-RACIAL}

A figura 1 representa a cor das pessoas com AF por autodeclaração, dado colhido dos próprios acometidos durante a pesquisa de campo: $35 \%$ dos informantes disseram ser morenos; $15 \%$, brancos; $13 \%$ se autodeclararam negros, e $7 \%$ consideram-se pretos.

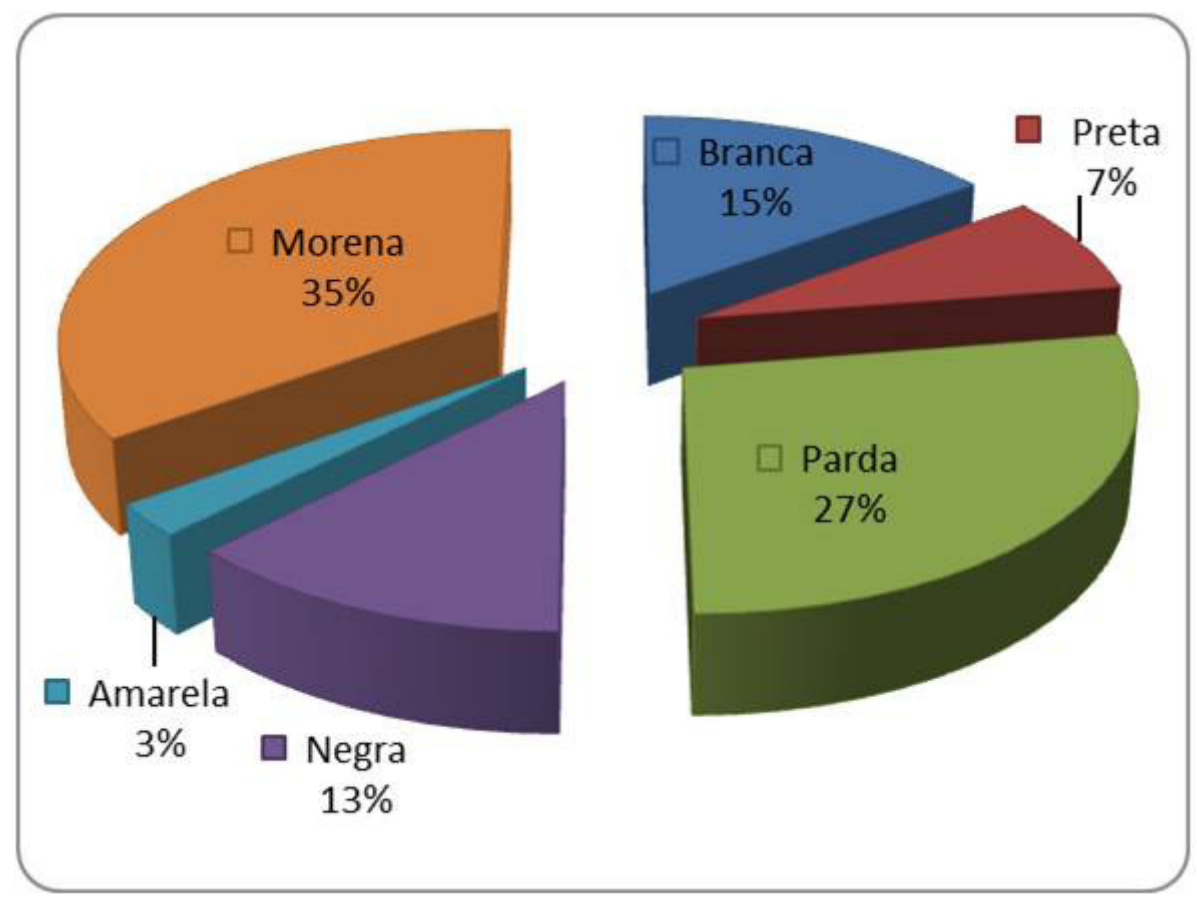

Figura 1. Cor autodeclarada da amostra de indivíduos HB*SS entrevistados no Hemopa, Belém, $2011(n=40)$. Fonte: pesquisa de campo. 
$\mathrm{Na}$ pesquisa seguiu-se a nomenclatura do Instituto Brasileiro de Geografia e Estatística em relação aos indicadores de "cor/raça" (Brasil 2011) uma vez que estes são os utilizados nas políticas públicas nacionais. No entanto, ordinariamente, os interlocutores não tem a oportunidade de autodeclarar a sua "cor/raça" no momento do cadastro de consultas, pois embora isto seja uma norma do Ministério da Saúde, deixou de ser rotina na instituição, tornando-se uma espécie de tabu (Leach 1983) no local, o que é um limitador das informações geradas no hemocentro paraense.

Este tabu ao qual os interlocutores estão sujeitos deve-se à "perda de tradição" no estabelecimento de saúde, para "evitar constrangimentos entre os pacientes" ou ainda porque os indivíduos não costumam responder à indagação pelo fato de "nem eles mesmos saberem a sua cor", palavras colhidas informalmente nos setores administrativos da instituição.

O quesito $\operatorname{cor}^{12}$ é uma categoria de grande importância para a avaliação das estatísticas em saúde. Visa representar a diversidade étnico-racial do Brasil e, como consenso ideológico, permite abrir espaços de debate com a intenção de abordar aspectos que são latentes em todo o território nacional: o preconceito, o racismo e a intolerância com o diferente (Adorno et al. 2004). No entanto, para diversos segmentos do Setor Saúde ainda não está evidente a importância da coleta adequada dessa informação para o planejamento de políticas públicas (Maio e Monteiro 2005).
A Fundação Hemopa trabalha com as informações "branca", "preta", "parda" e "indígena" nos prontuários, distinta da classificação do IBGE (Brasil 2011).

A Figura 2 mostra uma comparação entre a cor registrada no prontuário médico, gerada pelo cadastro do hemocentro, a cor presumida, indicada pelo atendente, sem participação do usuário (Série 1) e a cor autodeclarada pelos interlocutores durante a pesquisa de campo (Série 2). Os dados mostram uma diferença geral entre as declarações, tanto de registro (Série 1) como de relato (Série 2), tendo sido incluídas as cores de pele "morena", "negra" e "amarela", que não foram encontradas ou citadas nos prontuários médicos.

A classificação de "pardos" no prontuário médico representa $70 \%$ da amostra; no entanto, em relação à mesma cor autodeclarada, o percentual equivale a apenas $27 \%$. Para "brancos" os dados são coincidentes, com representação de 15\%. Os "pretos" no prontuário médico somam $2 \%$ e os autodeclarados são 7\%. A cor "não informada" chega a 13\% na amostra e traduz somente os prontuários médicos que não referenciam o dado em seu conteúdo. A cor "amarela" equivale a 3\% da amostra autodeclarada, embora nenhum dos entrevistados tivesse traços orientais. A cor "negra" soma 13\% entre os autodeclarados. Os que se dizem "morenos” (cor que não é padrão no IBGE) somam 35\%, uma ressignificação que talvez tenha sido incorporada às diversas formas de identidade a que o povo brasileiro tem atravessado ao longo do processo histórico (Munanga 2004). 
A autodeclaração da cor/raça é um instrumento importante, que não deveria ser descuidado em instituições de saúde, por ser um direito adquirido em razão de políticas públicas diferenciadas, voltadas aos grupos mais vulneráveis socialmente. A identidade associada à cor/raça nos serviços públicos voltados para esses agrupamentos tem por finalidade garantir o aporte adequado de recursos/verbas na área da saúde - e outros benefícios - para essas populações.

A Lei 10.678/2003 (Brasil 2010a) que instituiu a Política de Promoção da Igualdade Racial e a Lei 12.288/2010 (Brasil 2010b) que criou o Estatuto da Igualdade Racial estabelecem diretrizes para a Saúde da População Negra e outros requisitos básicos para a promoção da saúde, qualidade de vida e equidade social das pessoas que se autoclassificam como "negras" (pretas e pardas).
De acordo com Miriam Abramovay et al. (2002: 9) a vulnerabilidade social é tratada aqui como o "resultado negativo da relação entre a disponibilidade dos recursos materiais ou simbólicos dos atores, sejam eles indivíduos ou grupos e o acesso à estrutura de oportunidades sociais, econômicas, culturais que provêm do Estado, do mercado e da sociedade".

Por envolver um grupo que possui uma doença crônica, com recursos econômicos limitados, que lida com a discriminação sociorracial e que declara dificuldade de acesso aos serviços do SUS, pode-se classificar a AF como sendo uma enfermidade com agravantes que estão diretamente relacionados aos Determinantes Sociais em Saúde (Buss e Filho 2007) que contribuem com as complicações fisiológicas inerentes à doença.

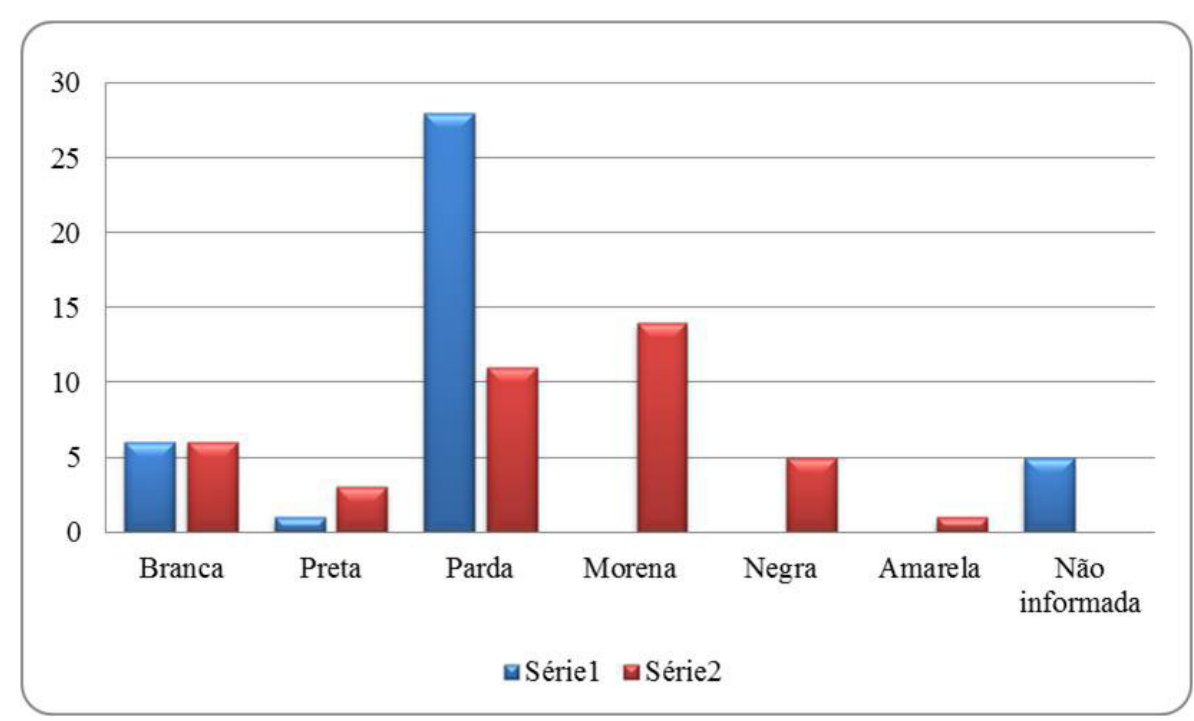

Figura 2. Cor da pele de pessoas com Anemia Falciforme no Pará: cor indicada no prontuário médico (Série 1) e cor autodeclarada em amostra da população HB*SS (Série 2), $n=40$. Fonte: pesquisa de campo, 2010. 


\section{O CORPO DOENTE ENQUANTO FENÔMENO BIOCULTURAL: DIAGNÓSTICO, PRECONCEITO E TABU}

O termo biocultural está relacionado entre outros aspectos - a processos que ocorreram ao longo de pelo menos sete milhões de anos de história evolutiva humana, que interconectaram a biologia e a cultura do Homo sapiens e que estão vinculados ao nosso comportamento, à saúde e à doença, a fatores ambientais e climáticos, a escolhas alimentares (dieta), a migrações e fluxos gênicos (Morán 1990; Lewin 1999). Assim, a expressão biocultural, de uso antropológico, aborda aspectos biológicos, evolutivos, culturais, sociais, ecológicos e ambientais das relações de saúde e doença que compõem a vida humana em sociedade (Jackson 2000; Silva 2009).

$\mathrm{O}$ diagnóstico de $\mathrm{AF}$ enfrentou problemas ao longo de sua implantação e ainda se confronta com obstáculos de infraestrutura laboratorial em todo $\mathrm{O}$ país, inclusive, no Estado do Pará e, apesar do exame diagnóstico existir há mais de duas décadas (Naoum e Bonini-Domingos 2007), apenas no ano de 2010 a cobertura do "teste do pezinho", que pode detectar hemoglobinopatias desde o nascimento (Garanito 2008) e é efetuado em recém-nascidos — foi concretizada, ainda que parcialmente, em Belém e no interior do Estado.

Apesar dos exames serem gratuitos e já regularmente distribuídos na rede pública, o fato de diagnosticar o novo paciente de AF em toda a hemorrede não define a questão, pois a cobertura de saúde exige procedimentos que vão além da simples detecção. Por conseguinte, conviver com AF é uma experiência que demanda diariamente inúmeros comportamentos, relações, percepções e ações em saúde que fazem parte do entendimento sobre o próprio diagnóstico, sobre o "corpo doente" e, ainda, sobre o cotidiano das pessoas que experienciam o agravo. Constatou-se que a percepção dos interlocutores em relação ao seu corpo é intensamente subjetiva, porque os mesmos medeiam interpretações que variam entre ser doente, estar doente, ter uma doença e também viver com $\mathrm{AF}$ como uma experiência em si, como existência que é diferenciada dos outros que não convivem com o agravo.

A percepção de ter sofrido preconceito e discriminação na amostra analisada chega a 57\%. Conceitos entendidos como atitudes de desrespeito, sujeição, aborrecimento ou constrangimento, sobretudo quando o assédio discriminatório em relação ao "doente" ou à pessoa com AF se dá no trabalho, na escola, vizinhança, família ou instituição de saúde, que resultam de informações incorretas ou limitadas sobre a doença por parte dos sujeitos que discriminam.

No seu dia-a-dia, os interlocutores com AF no Pará frequentemente sofrem com estereótipos, sendo desqualificados em diversos estágios da vida e estigmatizados com apelidos como: "olhos amarelos" (conjuntivas com coloração alterada), "buchão" (quando com esplenomegalia), "coitadinha" (sentimento de pena em relação à síndrome), "fraco" (visto como anêmico), "baixinha" (por ter baixa estatura), 
"esqueleto" (por causa de anorexia), "amarelão" (pela tonalidade da pele), "boneca de vidro" (relacionada às persistentes crises de dor), "perna podre" (em ocasião de úlcera de perna), "bracinho" (morfologia diferente do braço pós-AVC), "doente" (incapacitado para o trabalho), além de vivenciar situações em que outras pessoas se afastam do informante por medo de "contágio" (fomite ${ }^{13}$ ), circunstâncias que contribuem substancialmente para desestruturar a autoestima dos interlocutores em todos os sentidos possíveis.

Em diversos espaços de saúde pública no Pará, como no próprio hemocentro e em hospitais, prontos-socorros, postos de saúde, unidades básicas, entre outros, locais frequentados pelos interlocutores no decorrer do tratamento ou no surgimento de crises, os mesmos são taxados sistematicamente como "vampiro", "vampirinho", ou "morcego" (devido à necessidade constante de transfusões), "manhoso" (por não acreditarem em sua dor) ou "viciados" (quando são tratados como dependentes de analgésicos) e ainda constatam que faltar à consulta hematológica em ocasiões pontuais é o mesmo que "perder a mega-sena 'duas' vezes” (comentário de um profissional de saúde, que reforça a relação de poder e hierarquia quando enfatiza a impossibilidade quase profana de não perder o retorno clínico sem antes saber o motivo de o usuário ter se ausentado da avaliação ambulatorial), atos que os magoam profundamente, gerando momentos de consternação e lágrimas, sendo impossível não se sen- sibilizar por depoimentos tão intensos, de pessoas que nunca foram ouvidas.

Em comparação à situação de discriminação vivenciada pelos interlocutores no estado do Pará, o preconceito entre mulheres negras com AF no estado da Bahia tem sido sistematicamente naturalizado nos serviços de saúde, conforme indicam Cordeiro e Ferreira (2009: 6):

"Com a discriminação incorporada como habitus, sua manifestação assume diversas formas, podendo ser diretamente, com regras e códigos que estabelecem distinção e preferências que geram espaços de poder e proporcionam a exclusão explícita de vários segmentos sociais. Envolve ainda situações que expõem pessoas a constrangimentos, atingidas em sua dignidade humana."

Indivíduos que se encontram "de fora" da experiência de viver com AF, pessoas com quem os interlocutores mantêm toda sorte de sociabilidades, costumam classificar o corpo dos informantes como "doente", quando na verdade a fragilidade da doença nem sempre é reconhecida por eles próprios, reforçando a ausência ou precariedade de informações sobre AF na sociedade.

Quando indagados sobre "se sentir doente" por ter AF, 62,5\% das pessoas relataram não se sentir doentes em decorrência do agravo e, entre outras falas, discorreram que tem uma doença ou que tem um problema com limitação; $37,5 \%$ dos que afirmaram se sentir doentes também expuseram situações de preconceito, dificuldade de acesso 
ao atendimento de saúde e a ausência ou restrição de apoio familiar em momentos de adoecimento como agravantes de sua situação, como pode ser observado nos relatos a seguir:

"Eu não sou doente, tenho um problema, com as limitações, apenas isso. Nem todos os meus amigos sabem que eu tenho $\mathrm{AF}$, nem falo pra eles pra que não sintam pena de mim (Ivone, 30 anos, técnica em agroindústria, interior do estado)."

"Não. Nunca pensei desta forma. Quando descobri que tinha a AF, procurei saber o que era e isso me ajudou a entender que eu tinha uma doença e que em determinados momentos ficaria doente, mas não que era uma doente (Joana, pedagoga, 35 anos, Belém).”

A condição de ser doente ou de ter uma "doença na primeira pessod", porém visualizada por uma "segunda pessod" - nesse caso, um agente exógeno - é uma noção que carrega consigo a ideia de perigo iminente, como um "modelo maléfico" referido por Laplantine (2004: 101), que pontua:

"Para que nossa exploração da constituição do discurso etiológico seja completa, convém então (...) fazer a distinção entre um modelo que chamaremos de "maléfico" e outro que chamaremos de "benéfico". Esse último esclarecimento vai nos permitir apreciar até que ponto a doença, longe de ser uma experiência bruta [...], é principalmente ambivalente e relativa a sistemas de avaliação que informam, ao mesmo tempo, a prática do terapeuta e a experiência do doente (Laplantine 2004: 101).”
Em consequência, a moléstia que se manifesta no corpo, que é privadora de sentidos e de normalidade, coaduna a transferência de significado para o próprio sujeito que conhece o seu corpo, quando se ajuíza que a doença propriamente dita "não é apenas um desvio biológico, mas é também um desvio social, e o doente é vivido pelos outros e se vê ele mesmo como um ser socialmente desvalorizado. (...) Ele faz parte dos que René Lenoir ${ }^{14}$ (1974) chama de 'os excluídos"' (Laplantine 2004: 103), conforme pode ser observado nos seguintes relatos:

"Eu não tenho coragem de fazer nada, eu trabalhar, é difícil. Eu nunca me habituei, eu tento esquecer que tenho essa doença, tem hora que o corpo não ajuda, que o corpo fica pedindo cama, é muito complicado (Carmem, 37 anos, auxiliar operacional, interior do estado)."

"Quando estou com as dores no corpo, eu me sinto desprezado (olhar triste e aspecto choroso), o dia-a-dia fica mais difícil, todo mundo sai. Eles (a família) não podem fazer nada, eu não posso pegar sol nem chuva, não posso jogar bola, futebol, eu sinto vontade, mas não posso jogar, eu não tenho condições, fico cansado, dói as pernas (Abel, 21 anos, desempregado, interior do estado)."

E avigorando a ideia de privação do "modelo maléfico", aquele mesmo corpo com AF é o que não pode tomar banho de igarapé ou no rio, que evita entrar na piscina ou ficar com roupa molhada após a praia por causa do frio, que pode evoluir rapidamente para dores 
ósseas ou crises álgicas sem precedentes. É um corpo definido como locus da doença, de uma percepção de si que é difícil e complicada tanto para o indivíduo como para a sua família, que causa embaraço e pranto na hora de delimitar o se sentir doente, especialmente pelo fato de ter vontade de fazer o que quer e não ter possibilidade por causa da doença, mas que prossegue porque se acostumou àquela condição.

Porém, nem todos os informantes com AF evitam sair de casa ou procurar emprego, tem pânico de ir à praia ou viajar, porque cada pessoa é, intrinsecamente, diferente da outra. Cada pessoa com AF é uma "caixinha de surpresas", como declarou a mãe de uma jovem ao relatar sobre a sucessão dos dias de sua filha única, e o episódio de ser ímpar é um reflexo biológico do próprio agravo, por causa da variabilidade da doença.

$\mathrm{Na}$ sala de transfusão pediátrica do hemocentro paraense, em entrevista com uma adolescente - que no momento da conversa recebia uma bolsa de hemácias para estabilizar o seu quadro álgico - e que estava acompanhada pela mãe, indagou-se à acompanhante sobre a "sensação" que teve ao receber o diagnóstico $H B^{*} S S$ de sua filha:

“Ah! Foi... "Ixi”! [Expressão corporal e linguística de "surpresa"]. Até quando ela nasceu fui percebendo as crises. Nada dos exames diagnosticarem o certo. Desde os seis a oito meses de idade vivia direto no hospital. Fui orientada pela médica a evitar filhos por causa da anemia falciforme, que dá mais em gente de cor morena.
Quando eu descobri que era $\mathrm{AF}$ foi mesmo que me dá uma facada. Assim, aos poucos, fui me adaptando, agora tá mais tranquilo. No começo foi complicado de aceitar (Benedita, do lar, mãe de adolescente de 14 anos com AF)."

O tabu (Leach 1983) relacionado ao corpo, que acompanha a vida de pessoas com AF é uma construção elaborada socialmente, constituída em limitações que, além de biológicas ou fisiológicas são, também, moldadas por aspectos linguísticos e de comportamento cultural, que conformam os modos de agir e de ser dos indivíduos pesquisados, inclusive quando relacionados a situações como, por exemplo, a (im) possibilidade de gerar filhos ${ }^{15}$ ou de explanar sobre o próprio tom de pele.

A existência de tabu é manifestada como um fato quando não se pergunta a cor das pessoas no hemocentro justamente para que o debate não seja suscitado, porque no Brasil não é costume da sociedade elaborar perguntas complexo-polêmicas, pois perguntar sobre cor assemelha-se a falar sobre raça num país mestiço e sem preconceitos como declara o mito da democracia racial (Guimarães 2003) ou mesmo pelo preconceito de não ter preconceito (Bastide e Fernandes 1955), costume difundido como um processo ideológico de nossa sociedade, realidade bastante atual no que diz respeito às diversas formas de racismo presentes em todo o país (Munanga 2003).

No caso da AF, o agravamento físico, a diferença sutil - quando há - na aparência da tonalidade da pele ou 
da conjuntiva, a estatura mediana ou as constantes internações devidas a inúmeros fatores já relatados, são suficientes para que as pessoas sejam vitimizadas com acintes de péssimo gosto, bullying entre as crianças, assédio moral no trabalho, alcunhas pejorativas, que reproduzem a violência do preconceito ou a penalização dos interlocutores como coitadinhos, estigmatizando ele ou ela como doente, com um sentimento caridoso de pesar, o que, em última instância, reforça a tese de um desconhecimento por parte da sociedade do que vem a ser $\mathrm{AF}$ e, principalmente, que o acolhimento humanizado nos serviços de saúde de maneira geral não é como "ganhar na mega-sena", mas é uma responsabilidade do estado, que deve alocar recursos aos grupos suscetíveis e dedicar-se à compreensão do contexto regional do agravo, fortalecendo políticas específicas, de cunho multidisciplinar, para fornecer atenção diferenciada às pessoas com AF, garantindo a equidade na utilização do Sistema Único de Saúde.

\section{CONSIDERAÇÕES FINAIS}

Atualmente, a AF enquanto fenômeno biológico já bastante estudado ainda é uma moléstia compreendida como incurável pela maioria dos interlocutores, embora já haja potenciais tratamentos, apesar de em fase experimental, como é o caso do Transplante de Medula Óssea $(\mathrm{TMO})^{16}$ para receptores compatíveis dentro ou fora da família (Pieroni et al. 2007). Este tratamento pode trazer enormes repercussões na forma como se lidará com a doença e seus acometidos no futuro. No entanto, enquanto um fato social (Durkheim 2001) que contribui para os processos de vulnerabilidade social dos indivíduos com o agravo, a AF é objeto pouco frequente na pesquisa brasileira.

As narrativas sobre o cotidiano dos sujeitos com AF são fundamentais para que os fatos sejam percebidos em essência, compreendendo aquilo que os seres humanos conceituam como adoecimento, saúde e doença, na perspectiva de que, com isso, consigamos nos aproximar das diversas visões de mundo que trazem consigo e, assim, englobando os demais aspectos de seu dia-a-dia como as dificuldades estruturais e familiares, angústias, expectativas, rituais e sociabilidades, consigamos suscitar ainda a possibilidade de contribuir para a criação de políticas públicas adequadas às suas necessidades, especialmente na região Amazônica, onde há ainda grande carência de pesquisas e serviços de saúde adequados às diferentes populações da região (Silva 2006).

Esta análise da AF buscou envolver aspectos evolutivos, biológicos, epidemiológicos e de prevalência da síndrome, e analisar as situações de vulnerabilidade e representação social de saúde e doença através de narrativas gentilmente cedidas pelos interlocutores nas "conversas com finalidade". Conjecturou também sugerir que a humanização dos serviços de saúde pública deve caminhar lado-a-lado com as aspirações dos usuários do SUS, com decisões que devem partir de toda a sociedade, reconhecendo que os obstáculos que permeiam a 
saúde paraense - e brasileira - em sua totalidade ainda são muitos.

Abordamos ainda o juízo de averiguar a experiência-próxima (Geertz 2000) que se constitui com as vicissitudes dos indivíduos em seu dia-a-dia, que organizam a vida em torno da manutenção do seu tratamento ou do isolamento social em que estão imersos por ações externas à doença - como acintes e estereótipos -, com a finalidade de expor alguns dos mecanismos que colaboraram ao longo do tempo com a situação de saúde de agrupamentos humanos acometidos pela AF.

Do ponto de vista das políticas públicas, convém lembrar ainda que a legitimidade de indagar sobre a cor dos usuários do SUS, como demonstrado, é abertamente tolhida nos espaços de saúde pública por constrangimentos históricos, que urgem ser desmistificados em nossa preconceituosa sociedade. A dificuldade de falar sobre a questão da cor/raça no Brasil é um sintoma presente na sociedade como algo invisível, que não está na “ordem do dia" do embate político-administrativo do Estado, e realmente não está porque tabus sobre cor e raça constituem a sinuosidade do mito de nossa "democracia racial".

A AF é uma síndrome imprevisível, com sintomas que apenas as pessoas que convivem com ela conseguiriam descrever, por experimentar, por exemplo, perspectivas de equilíbrio e desequilíbrio - o rebote $^{17}$ - às vezes em questão de algumas horas apenas, que constantemente acompanham os indivíduos. Exatamente por isso, são sujeitos com peculiaridades para um grande enredamento, como: espaços de solidariedade, de redução de danos, de atendimento humanizado, de capacitação técnica, de supressão de preconceitos e de sensibilização de profissionais de saúde em relação às suas vivências, atitudes imprescindíveis para que os interlocutores tenham a caução de uma terapia que seja efetivamente holística.

O agravo da AF suscita políticas públicas urgentes em feitios de precoce diagnóstico, compreensão de terapêuticas acadêmicas e não acadêmicas ${ }^{18}$, acolhimento na Rede Básica de Saúde, treinamento constante do aparato multiprofissional - como, por exemplo, orientações clínicas sobre a doença de modo rotineiro e o aconselhamento genético humanizado - e enfrentamentos de rotina, como estímulo à adesão ao tratamento e a cobertura em saúde, que precisa de ampliação da capital do Estado para o interior.

Os interlocutores da pesquisa, os outros, são pessoas que demonstram como é complexa e difícil a situação de fazer parte de um sistema público de saúde que é instável, em um estado que enfrenta problemas de longa duração, no qual os sujeitos devem ser estimulados a ressignificar necessidades, direitos, vontades, espaços de construção de equidades e atitudes de solidariedade, para que os mesmos sejam, de fato, incluídos socialmente.

A universalização do SUS (Brasil 1990) propõe que todas as pessoas tenham os serviços de saúde garantidos no Brasil, entretanto, o aparato jurídico só pode ser instrumentalizado mediante o reconhecimento contextual, sistemático e constante das diversas coletividades 
do país. Em particular, reconhecer os aspectos bioculturais da população da região Amazônica é fundamental para que os grupos remanescentes de quilombos, povos indígenas e outros que compõem a nossa singularidade, consigam obter respaldo político, social, econômico, educacional e informações em saúde capazes de organizar suas vidas de maneira mais efetiva e harmoniosa.

\section{NOTAS}

${ }^{1}$ De acordo com Lewin (1999: 37), o fluxo gênico entre as populações, através da migração de indivíduos entre populações e o intercruzamento, reduzirá as diferenças à medida que os alelos das populações separadas se misturarem, até o momento em que as espécies de populações geográficas apresentem perfis genéticos próprios (politípicas).

${ }^{2}$ Haplótipo é "a combinação de alelos que não se encontram em equilíbrio de ligamentos, ou seja, existem combinações de alelos em "excesso" e há uma "falta" de combinações de outros alelos" e frequência gênica é "a composição genética de uma população calculando as frequências de genes e de genótipos que a compõem". Os conceitos foram obtidos em: http://sti. br.inter.net/rafaas/biologia-ar/genetica. htm. Acesso em 02 Jan.2012.

$3 \mathrm{O}$ Blog http://vivercomanemiafalciforme.blogspot.com/ é um exemplo de divulgação em redes sociais que demonstra muitos relatos sobre como as pessoas com o agravo "vivem" e se relacionam com a Anemia Falciforme em seu cotidiano social, econômico, político e também nas relações entre saúde e doença dos mesmos.

${ }^{4}$ Em seminário na Universidade Federal do Pará sobre "Pesquisa em saúde e violência", a Prof. ${ }^{a}$ Dr. $^{a}$ Maria Cecília de S. Minayo utilizou o termo "conversa com finalidade" para identificar o processo de interação entre o sujeito da pesquisa (o pesquisador) e o seu interlocutor (o entrevistado), enfatizando que para a produção de uma pesquisa em perspectiva, é necessário que duas pessoas se encontrem em uma "conversa com finalidade", que seria a intensa interação entre ambos, que deve produzir a crítica lado-a-lado e, portanto, investigar opiniões, percepções, valores, crenças, atitudes, práticas e relações sociais dentro de um panorama que é por si mesmo, um exercício dialético e contextual (UFPA/Setembro, 2011). Outros detalhes em Minayo (2000).

${ }^{5}$ Sobre o assunto Sevalho (1993: 350) afirma: "Acredito na plurisecularidade das relações que forjam as representações de uma cultura da saúde e da doença, admitindo o caráter provocativo que reveste tal expressão. Eis porque, mais do que mudanças, procuro as permanências culturais na longa duração".

${ }^{6}$ Segundo Alves e Rabelo (1998: 113): “Ao incorporarmos essa discussão aos estudos em antropologia [...] a atenção é deslocada da doença como fato (seja dado empírico ou signo) para o curso da doença como experiência. Esse é um campo de investigação que só se estabelece plenamente quando a relação entre representações e práticas é sujeita a críticas e reformulação".

${ }^{7}$ Determinantes Sociais em Saúde (DSS) são as condições sociais em que as pessoas vivem/trabalham e que afetam a saúde, como: os mecanismos físico-materiais (diferença de renda e outros), os aspectos psicossociais (percepções de desigualdades sociais que causam estresse), os enfoques ecossociais e multiníveis (integração de abordagens dinâmicas individuais e grupais) e o desgaste do capital social (relacio- 
nado à iniquidade de renda e às relações de coesão social - solidariedade e confiança entre pessoas e grupos) são alguns exemplos que podem contribuir para o surgimento de DSS (Buss e Filho 2007).

${ }^{8}$ Os dados sobre benefício/auxílio doença podem ser visualizados no site: http:// www.mpas.gov.br/. As normas para ter acesso aos serviços estão disponíveis em: http://www.normaslegais.com.br/ trab/1previdenciaria200409.htm. Acesso em 10 Mar.2012.

9 Para Laplantine (2004: 227), a doençamaldição "é o acidente que ocorre por acaso, pelo destino, pela fatalidade, contra o qual nada se pode. O doente (ou todo o grupo) vive então o que lhe acontece como um escândalo e uma injustiça. Considerandose a uma vítima que padece pelo que não provocou, ele proclama a sua inocência e sua indignação".

${ }^{10}$ Kabengele Munanga (2003: 10) afirma que a noção sobre "raça" na sociedade brasileira, parte de um estigma corporal que representa uma "categoria social biologizante", afirmando que o uso generalizado do conceito de racismo "pode constituir uma armadilha ideológica, na medida em que pode levar à banalização dos efeitos do racismo. [...] O difícil é aniquilar as raças fictícias que rondam em nossas representações e imaginários coletivos".

${ }^{11} \mathrm{Em}$ respeito à condição vulnerável de doença crônica, Canesqui et al. (2008: 2311) relatam que "trata-se de dar atenção aos aspectos privados, à vida cotidiana, às rupturas das rotinas, ao gerenciamento da doença e à própria vida dos adoecidos, cujos cuidados não se restringem aos serviços de saúde e ao contato com os profissionais".

${ }^{12}$ Segundo Adorno et al. (2004), o quesito cor é baseado em instrumentos de informação em saúde e também em trabalhos que passaram a identificar diferenciais en- contrados a partir dos dados de mortalidade, que utilizaram a informação cruzando com as categorias "pretos", "brancos" e "pardos" em todo o país, como forma de sensibilização e de contribuição para a formação do pessoal de saúde à questão da discriminação social e racial em todo o país.

${ }^{13}$ Fomite (palavra da língua inglesa) ou fômite é qualquer objeto inanimado ou substância capaz de absorver, reter e transportar organismos contagiantes ou infecciosos (de germes a parasitas), de um indivíduo a outro. Fonte: http://pt.wikipedia. org/wiki/F\%C3\%B4mite. Acesso em 10 dez.2011. Outras informações sobre o assunto podem ser encontradas em: Terris, M. 1985. Changing relationship of epidemiology and society: Robert Cruikshank lecture.

${ }^{14}$ Conforme referência na obra de Laplantine (2004: 261): Lenoir, R. 1974. Les exclus. Paris: Le Seuil.

${ }^{15} \mathrm{O}$ tabu forjado como um "aconselhamento" por instituições de saúde pública pelo Brasil no sentido de coibir ou literalmente proibir (evitar) a concepção de filhos por parte de mães e pais com o traço falciforme ou a anemia falciforme foi debatido no VI Simpósio Brasileiro de Doença Falciforme, em Outubro de 2011 (Fortaleza/CE), quando mulheres com $H^{*} S$ declararam publicamente o desejo e o direito de gerar filhos, o que causou um impacto político durante o congresso.

${ }^{16}$ Informações mais detalhadas nos sites: http://www.abrale.org.br/doencas/transplante/index.php e http://www.ameo.org. br/interna2.php?id $=5$

${ }^{17}$ Rebote é a recaída que acomete muitas vezes as pessoas com AF quando infecções seguidas ocorrem com os sujeitos, deixando-os fragilizados, chegando a experimentar várias internações hospitalares em curto período de tempo. O termo foi usado pelo Prof. Dr. Paulo Cesar Naoum durante sua apresentação no VI Simpósio 
Brasileiro de Doença Falciforme, 2011, Fortaleza (CE).

${ }^{18}$ Seguindo a concepção de Débora Diniz (1997) quando enfatiza as diversas noções de medicina que são classificadas como "Acadêmicas" (o conhecimento médico) e "Não Acadêmicas" (o conhecimento empírico ou folk, medicine), em se tratando de modelos dos sistemas oficiais de saúde no Brasil, significa analisar de que maneira as categorias em questão são representadas em sociedade.

\section{REFERÊNCIAS}

Abramovay, M., M. G. Castro, L. de C. Pinheiro, F. de S. Lima \& C. da C. Martinelli. 2002. Juventude, violência e vulnerabilidade social na América Latina: desafios para politicas públicas. Brasilia: Unesco, BID. 192 p.

Adorno, R de C.F., A. T. de Alvarenga \& M. da P. Vasconcellos. 2004. Quesito cor no sistema de informação em saúde. Estudos Avanşados 50 (18): 1-6.

Alves, P. C. \& M. C. R. Rabelo. 1998. Antropologia da saúde: traçando identidades e explorando fronteiras. Rio de Janeiro: Fiocruz, RelumeDumará. 248 p.

Bastide, R. \& F. Fernandes. 1955. Relaçoes raciais entre negros e brancos em São Paulo. UnescoAnhembi. 554 p.

Batista, T. F. 2008. Con(vivendo) com a anemia falciforme: o olhar da enfermagem para o cotidiano de adolescentes. Dissertação de Mestrado. Programa de Pós Graduação em Enfermagem, Universidade Federal da Bahia, Salvador.

Brasil. 1990. Ministério da Saúde. Lei 8080/90. Dispõe sobre as condições para a promoção, proteção e recuperação da saúde, a organização e o funcionamento dos serviços correspondentes do Sistema Único de Saúde do Brasil. Brasília.

Brasil. 1993. Ministério da Saúde. Proto- colo para portadores de síndromes falciformes. Caderno Hemominas 1: 1-8.

Brasil. 2006. Ministério da Saúde. Guia do Sistema Único de Saúde: doença falciforme. Brasilia.

Brasil. 2007. Ministério da Saúde. Biblioteca Virtual em Saúde. Disponível em http:// bvsms.saude.gov.br/. Acesso em 30 nov. 2010.

Brasil. 2010a. Lei 10.678/2003. Cria a Secretaria Especial de Políticas de Promoção da Igualdade Racial.

Brasil. 2010b. Lei 12.288/2010. Estatuto da Igualdade Racial, destinado a garantir à população negra a efetivação da igualdade de oportunidades, a defesa dos direitos étnicos individuais, coletivos e difusos e o combate à discriminação e às demais formas de intolerância étnica.

Brasil. 2011. Instituto Brasileiro de Geografia e Estatística. Disponível em www.ibge.org.br. Acesso em 20 fev. 2012.

Buss, P. M. \& A. P. Filho. 2007. A saúde e seus determinantes sociais. PHYSIS. Revista de Saúde Coletiva 17 (1): 77-93.

Calvo-González, E. \& V. S. Rocha. 2010. "Está no sangue": a articulação de ideias sobre "raça", aparência e ancestralidade entre famílias de portadores de doença falciforme em Salvador, Bahia. Revista de Antropologia USP 53 (1): 277-320.

Canesqui, A. M.; M. E. P. Castallanos, N. F. Barros \& J. Casulari. 2008. Olhares socioantropológicos sobre os adoecidos crônicos. Ciência e Saúde Coletiva 13 (2): 2309 2311.

Cançado, R. D. \& J. A. Jesus. 2007. A doença falciforme no Brasil. Revista Brasileira de Hematologia e Hemoterapia 29 (3): 61-64.

Cavalcante, I. M. S. 2011. Acesso e acessibilidade aos serviços de saúde em três quilombos na Amaz̧ônia Paraense. Dissertação de Mes- 
trado. Programa de Pós Graduação em Saúde, Sociedade e Endemias na Amazônia, Universidade Federal do Pará, Belém.

Cordeiro, R. C. \& S. L. Ferreira. 2009. Discriminação racial e de gênero em discursos de mulheres negras com anemia falciforme. Salvador: Esc. Anna Nery. Revista de Enfermagem 13 (2): 52-58.

Diniz, D. 1997. O que é isso que chamamos Antropologia da Saúde no Brasil? Revista Brasileira de Pós-Graduacão em Ciências Sociais I(1) 24-34.

Domingues, P. 2007. Movimento negro brasileiro: alguns apontamentos históricos. Tempo 23: 100-122.

Durkheim, E. 2001. As regras do método sociológico. São Paulo: Nacional. 165 p.

Fontanella, B. J. B; J. Ricas \& E. R. Turato. 2008. Amostragem por saturação em pesquisas qualitativas em saúde: contribuições teóricas. Cadernos de Saúde Pública 24(1): 17-27.

Garanito, M. P. 2008. Hemoglobinopatias: Interpretação do teste de triagem neonatal. Revista de Pediatria. Revisões e Ensaios 30 (3): 172-176.

Guerra, I. C. 2008. Pesquisa qualitativa e análise de conteúdo: sentidos e formas de uso. Portugal: Cascais, Princípia. 95 p.

Geertz, C. 2000. O saber local: novos ensaios em antropologia interpretativa, in Do ponto de vista dos "nativos": a natureza do entendimento antropológico. Tradução de V. M. Joscelyne, pp. 85-107. Petrópolis: Vozes.

Guimarães, A. S. A. 2003. Democracia Racial. São Paulo: Universidade de São Paulo/Departamento de Sociologia.

Hutz, M. H. 2010. História natural da anemia falciforme em pacientes da região metropolitana do Rio de Janeiro. Tese de Doutorado [1981], in IBraFH - Instituto Brasileiro de Doenca Falciforme e outras Hemoglobinopatias. Cartilha: Cem anos de diagnóstico.
Universidade Federal do Rio Grande do Sul: Porto Alegre.

Jackson, F. L. C. 2000. Adaptations to infectious disease, in Human biology an evolutionary and biocultural perspective, pp. 273-293. United States of America: Willey-Liss.

Laplantine, F. 2004. Antropologia da doença. São Paulo: Martins Fontes. 274 p.

Leach, E. R. 1983. Antropologia, in Aspectos antropológicos da linguagem: categorias animais e insulto verbal. Organizado por R. DaMatta. Tradução de G. A. Zaluar, pp. 170-198. São Paulo: Ática.

Lewin, R. 1999. Evolução humana. São Paulo: Atheneu. 526 p.

Maio, M. C. \& S. Monteiro. 2005. Tempos de racialização: o caso da "saúde da população negra" no Brasil. História, Ciências, Saúde-Manguinhos 12 (2): 419-446.

Mauss, M. 1979a. Marcel Mauss: antropologia, in Introdução a uma leitura de Mauss. Organizado por R. C. Oliveira. Tradução de R. L. M. Morel, D. M. Meirelles e I. Toscano, pp. 07-50. São Paulo: Ática.

1979b. Marcel Mauss: antropologia, in Ofício de etnógrafo, método sociológico. Organizado por R. C. Oliveira. Tradução de R. L. M. Morel, D. M. Meirelles e I. Toscano, pp. 53-59. São Paulo: Ática.

Minayo, M. C. 2000. O desafio do conhecimento: pesquisa qualitativa e saúde. Rio de Janeiro: 7. ed. São Paulo - Hucitec - Abrasco. 269 p.

Morán, E. F. 1990. O homem e o ambiente: uma relação complexa, in $A$ ecologia bumana das populações da Amazônia, pp. 2355. Petrópolis: Vozes.

Munanga, K. 2004. A difícil tarefa de definir quem é negro no Brasil. Estudos Avançados 50 (18): 01-07.

2003. Uma abordagem conceitual das noções de raça, racismo, identidade e etnia. Rio 
de Janeiro: Texto da Universidade de São Paulo. Palestra proferida no $3^{\circ}$ Seminário Nacional Relações Raciais e EducaçãoPENESB-RJ.

Naoum, P. C. 2011. Sickle cell disease: from the beginning until it was recognized as a public health disease. Revista Brasileira de Hematologia e Hemoterapia 33 (1): 01-10.

.2010. Hipótese multi-regional da hemoglobina S. Disponível em http://www.hemoglobinopatias.com.br/d-falciforme/ genebs.htm. Acesso em 20 dez. 2010.

2000. Interferentes eritrocitários e ambientais na anemia falciforme. Revista Brasileira de Hematologia e Hemoterapia 22 (1): 05-22.

Naoum, P. C. \& C. R. Bonini-Domingos. 2007. Dificuldades no diagnóstico laboratorial das hemoglobinopatias. Revista Brasileira de Hematologia e Hemoterapia 29 (3): 01-07.

Pante-de-Sousa, G.; R. C. M. Ribeiro, E. J. M. Santos, M. A. Zago \& J. F. Guerreiro. 1998. Origin of the hemoglobin $S$ gene in a northern Brazilian population: the combined effects of slave trade and internal migrations. Genética Molecular e Biologia 21 (4): 427-430.

Perin, C.; E. C. Filho, F. L. Becker, F. M. Aldisserotto, G. Z. Ramos, J. S. Antonello, C. O. P. Alexandre \& E. de C. Castro. 2000. Anemia Falciforme. Porto Alegre: Fundação Faculdade Federal de Ciências Médicas de Porto Alegre. Departamento de Ciências Morfológicas.

Pieroni, F., G. M. N. Barros, J. C. Voltarelli \& B. P. Simões. 2007. Transplante de células-tronco hematopoiéticas (TCTH) em doenças falciformes. Revista Brasileira de $\mathrm{He}$ matologia e Hemoterapia 29 (3): 327-330.

Sevalho, G. 1993. Uma abordagem histórica das representações sociais de saúde e doença. Cadernos de Saúde Pública 9(3): 349-363.
Silva, H. P. 2009. Variabilidade, raça e racismo: conversando sobre a diversidade biocultural humana, in Diversidade; Educação e Direitos: Etnologia Indigena, pp. 51-59. Organizado por J. F. Beltrão e L. Mastop-Lima. Belém: IEMCI-UFPA 53.

2006. A Saúde humana e a Amazônia no século XXI: reflexões sobre os objetivos do milênio. Novos Cadernos do NAEA/UFPA 9 (1):77-94.

Soares, L. F., B. Melo Neto, C. G. Sá, E. H. de Oliveira, B. A. C. Araújo de \& R. P. Veloso. 2009. Da mãe África aos filhos Brasil: expressão da herança genética para a anemia falciforme em estudantes do curso de farmácia da Universidade Federal do Piauí. RBAC 41 (3): 235-237.

Terris, M. 1985. Changing relationship of epidemiology and society: Robert Cruikshank lecture. Journal of Public Health Police 6 (1): 15-36.

Zago, M. A., M. S. Figueiredo \& S. H. Ogo. 1992. Bantu $\beta^{S}$ cluster haplotype predominates among Brazilian blacks. Am. J. Phys. Anthropol. 88: 295-298.

Recebido em 06/04/2012.

Aprovado em 15/11/2012. 